Journal of Agricultural Sciences
(Tarim Bilimleri Dergisi)

\title{
Secondary Metabolite Changes in Tedara (Bituminaria bituminosa L.) Genotypes in Different Growing Period
}

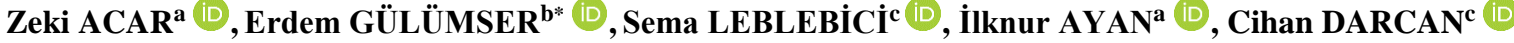 \\ ${ }^{a}$ Department of Field Crop, Faculty of Agriculture, University of Ondokuz Mayls, Samsun, TURKEY \\ ${ }^{b}$ Department of Field Crops, Faculty of Agriculture and Natural Sciences, University of Bilecik Seyh Edebali, Bilecik, TURKEY \\ ${ }^{c}$ Department of Molecular Biology and Genetics, Faculty of Arts and Sciences, Bilecik Seyh Edebali University, Bilecik, TURKEY
}

\section{ARTICLE INFO}

Research Article

Corresponding Author: Erdem GÜLÜMSER, E-mail: erdem.gulumser@ bilecik.edu.tr

Received: 19 August 2021 / Revised: 07 December 2021 / Accepted: 11 December 2021 / Online: 15 October 2022

Cite this article

ACAR Z, GÜLÜMSER E, LEBLEBiCI S, AYAN ILKNUR, DARCAN C (2022). Secondary Metabolite Changes in Tedara (Bituminaria bituminosa L.) Genotypes in Different Growing

Period. Journal of Agricultural Sciences (Tarim Bilimleri Dergisi), 28(4):723-731. DOI: 10.15832/ankutbd.984689

\section{ABSTRACT}

In this study, secondary metabolite amounts of leaf samples belonging to 12 different Bituminaria bituminosa (L.) C.H. Stirtion genotypes were determined at the beginning of growth, budding and at the beginning of flowering periods. Leaf samples belonging to $B$. bituminosa genotypes were dried under natural conditions and extracted using a microwave system (NEOS). Furanocumarins (psoralen and angelicin), isoflavonoids (daidzein, genistein) and isoflovan glycosides (daidzin and genistin) obtained by LC-MS / MS. While the secondary metabolite contents determined in B. bituminosa differed among growth periods, genotype difference was found to be more effective on these metabolite contents. As a result, all genotypes performed remarkably in terms of secondary metabolites. Besides, the number 12 genotype (Samsun-Kavak) was prominent in terms of angelicin, daidzein, genistein, daidzin, and genistin compared to the other genotypes.

Keywords: Animal health, Furanocoumarin, Isoflavonoid, Tedera

\section{Introduction}

Bituminaria bituminosa (L.) C.H. Stirtion (B. bituminosa) is a perennial species and is a member of the Leguminosea family is originated in Mediterranean. However, it shows a wide spreading in the natural flora of Turkey, South Europe, Crimea, Western Syria, Cyprus, the Caucasus, Israel, the North Africa, Portugal and Spain (Davis 1965).

B. bituminosa is a plant species which has rich content in terms of secondary metabolites. The amount of secondary metabolites that give the plant a distinctive odour varies significantly according to genotype and ecological conditions (Pecetti et al. 2007; Correal 2012; Real 2012). While these metabolites play a role in the defence mechanism of the plant, they also have beneficial effects on human physiology and diseases due to their bioactive molecules. Secondary metabolite content of $B$. bituminosa such as furanocoumarins, isoflavonoids and pterocarbans have pharmacological effects (Martínez et al. 2010). These substances are used in the cosmetic industry and in the treatment of vitiligo, psoriasis, fungal, eczema, sunburn, skin cancer, colon cancer, Mediterranean anemia, allergen diseases and relieving inflammation (Pistelli et al. 2003; Pazos -Navarro et al. 2013). While secondary metabolites and antioxidant substances in the plant positively affect the health of animals, they also improve the quality of animal products (Pecetti et al. 2007).

The literature shows that secondary metabolites of B. bituminosa may change depending on the growth periods. Study of Tava et al. (2007) determined in the leaves and stems of B. bituminosa plant psoralen and angelicin content. Walker et al. (2006) analysed these metabolites in April, August and November and the highest values were found to be in the samples collected in August. This is related to temperature and increases the furanocoumarin content of the plant with increasing UV light intensity (Bourgaud et al. 1995). In previous studies, the presence of pterocarpan and daidzein were determined in the Psoralea species (Boardley et al. 1986; Bouque et al. 1998; Pistelli et al. 2003).

In the present study, secondary metabolites (psoralen and angelicin, daidzein, genistein, daidzin and genistin) were determined in beginning of growth, budding, and in the beginning of flowering periods of 12 different $B$. bituminosa genotypes and changes in the amounts of these secondary metabolites were determined in three different physiological periods. 


\section{Material and Methods}

Seeds of B. bituminosa collected in 2012 from Samsun (8), Sinop (2) and Kastamonu (1) were used as plant material in the study. In addition, one genotype of Spain origin was also used in the study (Table 1).

Table 1- Localities of $B$. bituminosa genotypes

\begin{tabular}{llcc}
\hline \multirow{2}{*}{ No } & \multirow{2}{*}{ Collection Location } & \multicolumn{2}{c}{ Locations } \\
\cline { 3 - 4 } & Spain & North & East \\
\hline G1 & Kastamonu İnebolu & - & - \\
G3 & Samsun-Çatalzeytin & $41^{\circ} 58^{\prime} 32.8^{\prime \prime}$ & $33^{\circ} 46^{\prime} 10.4^{\prime}$ \\
G4 & Sinop Kanlıçay & $41^{\circ} 57^{\prime} 48.4^{\prime \prime}$ & $34^{\circ} 09^{\prime} 07.8^{\prime}$ \\
G5 & Samsun-KozağZ1 & $41^{\circ} 40^{\prime} 40.3^{\prime \prime}$ & $35^{\circ} 22^{\prime} 22.8^{\prime}$ \\
G6 & Samsun-Çarşamba & $41^{\circ} 28^{\prime} 05.1^{\prime \prime}$ & $35^{\circ} 49^{\prime} 56.8^{\prime}$ \\
G7 & Samsun-Bağkur & $41^{\circ} 04^{\prime} 35.1^{\prime \prime}$ & $36^{\circ} 40^{\prime} 09.0^{\prime}$ \\
G8 & Samsun- Baruthane & $41^{\circ} 18^{\prime} 39.0^{\prime \prime}$ & $36^{\circ} 20^{\prime} 02.5^{\prime}$ \\
G9 & Samsun-Nebyan & $41^{\circ} 19^{\prime} 08.5^{\prime \prime}$ & $36^{\circ} 19^{\prime} 13.6^{\prime}$ \\
G10 & Samsun-Kurupelit & $41^{\circ} 23^{\prime} 35.9^{\prime \prime}$ & $35^{\circ} 59^{\prime} 06.2^{\prime}$ \\
G11 & Sinop-Tingiroğlu & $41^{\circ} 22^{\prime} 16.0^{\prime \prime}$ & $36^{\circ} 11^{\prime} 46.7^{\prime}$ \\
G12 & Samsun-Kavak & $41^{\circ} 47^{\prime} 41.0^{\prime \prime}$ & $35^{\circ} 00^{\prime} 23.0^{\prime \prime}$ \\
\hline
\end{tabular}

The collected seeds were firstly sown into seed trays. Then, they were transplanted to Experimental Field of Agriculture Faculty of Samsun Ondokuz May1s University with 70x70 cm spaces in autumn during 2016. The properties of experimental area soil which were gathered from $0-15 \mathrm{~cm}$ deep were determined as a $\mathrm{pH}$ of $6.45,7.90 \% \mathrm{CaCO}_{3}$ and saltless $(0.052 \mathrm{mmhos} / \mathrm{cm})$. Plants were not irrigated and fertilized during the study. In the 2018 vegetation period; at the beginning of growth, budding and at the beginning flowering, the plants were harvested and the leaves were separated (Table 2). Besides, while sampling the leaves, genotypes with the same habitus were taken into account.

Table 2- Harvest dates of $B$. bituminosa genotypes

\begin{tabular}{lccc}
\hline Genotypes & Beginning of growth & Budding & Beginning of flowering \\
\hline Spain & 10.05 .2018 & 31.05 .2018 & 07.06 .2018 \\
Kastamonu İnebolu & 10.05 .2018 & 24.05 .2018 & 31.05 .2018 \\
Samsun-Çatalzeytin & 10.05 .2018 & 24.05 .2018 & 31.05 .2018 \\
Sinop Kanlıçay & 10.05 .2018 & 24.05 .2018 & 31.05 .2018 \\
Samsun-Kozağzı & 10.05 .2018 & 24.05 .2018 & 31.05 .2018 \\
Samsun-Çarşamba & 10.05 .2018 & 24.05 .2018 & 31.05 .2018 \\
Samsun-Bağkur & 10.05 .2018 & 24.05 .2018 & 31.05 .2018 \\
Samsun- Baruthane & 10.05 .2018 & 24.05 .2018 & 31.05 .2018 \\
Samsun-Nebyan & 10.05 .2018 & 24.05 .2018 & 31.05 .2018 \\
Samsun-Kurupelit & 10.05 .2018 & 24.05 .2018 & 31.05 .2018 \\
Sinop-Tıngıroğlu & 10.05 .2018 & 24.05 .2018 & 31.05 .2018 \\
Samsun-Kavak & 10.05 .2018 & 24.05 .2018 & 31.05 .2018 \\
\hline
\end{tabular}

B. bituminosa leaf samples taken from the genotypes were dried under natural conditions and then extracted with NEOS device (microwave system) in the ECO-Biotechnology Laboratory of Bilecik Şeyh Edebali University, Biotechnology Application and Research Centre. Secondary metabolite contents of the extracts were determined by LC-MS / MS. Secondary metabolites determined in leaf samples of B. bituminosa were psoralen, angelicin, daidzein, genistein, daidzin and genistin. Prior to the statistical analysis of the data obtained, transformation was applied and its suitability for normal distribution was examined. The results of the study were analysed by using the MSTAT-C statistical package program with regards to the split pilot design. Differences between genotype and physiological periods were determined by Duncan multiple comparison test. Besides, the correlation coefficients among all observed components were calculated by the in SPSS version 18.0, while the Principal component analysis (PCA) was carried out using the statistical software package PASW (18) Statistics Data Editor Program.

\section{Results and Discussion}

Mean squares and coefficient of variance for secondary metabolites and B. bituminosa genotypes are given Table 3. Accordingly, the difference between the growth periods, genotypes and the interaction between genotype $\mathrm{x}$ growth period were found to be significant at the $1 \%$ probability level for all secondary metabolites. 
Table 3- Mean squares and coefficient of variance for secondary metabolites and $\boldsymbol{B}$. bituminosa genotypes

\begin{tabular}{l|cccccc}
\hline $\begin{array}{l}\text { Source of } \\
\text { variation }\end{array}$ & $\boldsymbol{d} \boldsymbol{f}$ & Psoralen & Angelicin & Daidzein & Genistein & Daidzin \\
\hline Growth period (GP) & 2 & $42.09^{* *}$ & $7.17^{* *}$ & $138.33^{* *}$ & $9.81^{* *}$ & $278.07^{* *}$ \\
Genotype (G) & 11 & $15.94^{* *}$ & $2.08^{* *}$ & $327.98^{* *}$ & $172.38^{* *}$ \\
GPXG & 22 & $9.32^{* *}$ & $2.59^{* *}$ & $115.86^{* *}$ & $2.08^{* *}$ & $73.78^{* *}$ \\
\hline CV\% & & 0.46 & 7.52 & 3.73 & $68.66^{* *}$ & 3.37 \\
\hline
\end{tabular}

$* *: \mathrm{P} \leq 0.01$

The highest psoralen content was obtained at the beginning of flowering and genotype number 11 with $118.47 \mathrm{ppm}$; the lowest psoralen content was obtained in budding and genotype number 12 with 3.88 ppm. Psoralen content in growth periods was determined as the highest in the beginning of flowering, lower in budding and the lowest in the beginning of growth. When the genotypes were compared, the highest psoralen content was determined in genotype number 8 (89.87 ppm) (Table 4).

Table 4- Psoralen contents of B. bituminosa (ppm)

\begin{tabular}{|c|c|c|c|c|}
\hline Genotypes & Beginning of growth & Budding & $\begin{array}{l}\text { Beginning of } \\
\text { flowering }\end{array}$ & Average *** $^{2}$ \\
\hline G1 & $53.89 \mathrm{q}$ & $85.19 \mathrm{~h}$ & $64.49 \mathrm{mn}$ & $67.85 \mathrm{f}$ \\
\hline G2 & $34.51 \mathrm{x}$ & 24.14 B & $83.56 \mathrm{j}$ & $47.40 \mathrm{~h}$ \\
\hline G3 & $12.36 \mathrm{D}$ & $25.03 \mathrm{~A}$ & $43.29 \mathrm{v}$ & $26.89 \mathrm{k}$ \\
\hline G4 & $26.19 \mathrm{z}$ & $49.78 \mathrm{~s}$ & $43.31 \mathrm{v}$ & $39.76 \mathrm{i}$ \\
\hline G5 & $47.11 \mathrm{t}$ & $107.16 \mathrm{c}$ & $91.48 \mathrm{f}$ & $81.91 \mathrm{~b}$ \\
\hline G6 & $41.36 \mathrm{w}$ & $25.93 \mathrm{z}$ & $45.55 \mathrm{u}$ & $37.61 \mathrm{j}$ \\
\hline G7 & $23.15 \mathrm{C}$ & $104.66 \mathrm{~d}$ & $84.09 \mathrm{ij}$ & $70.63 \mathrm{~d}$ \\
\hline G8 & 72.441 & $87.40 \mathrm{~g}$ & $109.77 \mathrm{~b}$ & 89.87 a \\
\hline G9 & $50.52 \mathrm{r}$ & $84.63 \mathrm{hi}$ & $79.34 \mathrm{k}$ & $71.49 \mathrm{c}$ \\
\hline G10 & $79.57 \mathrm{k}$ & $62.86 \mathrm{o}$ & $63.76 \mathrm{n}$ & $68.73 \mathrm{e}$ \\
\hline G11 & $31.13 \mathrm{y}$ & $57.06 \mathrm{p}$ & $118.47 \mathrm{a}$ & $68.89 \mathrm{e}$ \\
\hline G12 & $65.28 \mathrm{~m}$ & $3.88 \mathrm{E}$ & $95.52 \mathrm{e}$ & $54.89 \mathrm{~g}$ \\
\hline Average $^{* * *}$ & $44.79 \mathrm{c}$ & 59.81 b & 76.89 a & \\
\hline
\end{tabular}

**: $\mathrm{P} \leq 0.01$ (While the interactions were lettered, capital letters were continued after the lowercase letters were finished). G1: Spain; G2: Kastamonu İnebolu; G3: Samsun-Çatalzeytin; G4: Sinop Kanlıçay; G5: Samsun-Kozağzı; G6: Samsun-Çarşamba; G7: Samsun-Bağkur; G8: Samsun- Baruthane; G9: SamsunNebyan; G10: Samsun-Kurupelit; G11: Sinop-Tıngıroğlu; G12: Samsun-Kavak.

The angelicin contents of the genotypes ranged from $0.11 \mathrm{ppm}$ to $19.61 \mathrm{ppm}$. The highest angelicin content was determined in genotype number 6 in the budding and the lowest angelicin content was determined in genotype number 5 in the beginning of flowering. When the growth periods were compared, the highest angelicin content was found in the budding (4.29 ppm) and the lowest angelicin content was found in the beginning of flowering $(0.60 \mathrm{ppm})$ (Table 5).

Table 5- Angelicin content of $B$. bituminosa (ppm)

\begin{tabular}{lccc|c}
\hline Genotypes & Beginning of growth & Budding & Beginning of flowering & Average $* *$ \\
\hline G1 & $0.16 \mathrm{tu}$ & $0.34 \mathrm{q}$ & $0.22 \mathrm{stu}$ & $0.24 \mathrm{i}$ \\
G2 & $0.97 \mathrm{i}-\mathrm{l}$ & $5.18 \mathrm{e}$ & $0.37 \mathrm{p}-\mathrm{s}$ & $2.17 \mathrm{e}$ \\
G3 & $1.85 \mathrm{~g}$ & $13.57 \mathrm{~b}$ & $0.71 \mathrm{k}-\mathrm{n}$ & $5.38 \mathrm{~b}$ \\
G4 & $1.82 \mathrm{~g}$ & $0.81 \mathrm{j}-\mathrm{m}$ & $0.52 \mathrm{n}-\mathrm{q}$ & $1.05 \mathrm{f}$ \\
G5 & $0.68 \mathrm{l-o}$ & $1.02 \mathrm{ijk}$ & $0.11 \mathrm{u}$ & $0.60 \mathrm{gh}$ \\
G6 & $0.32 \mathrm{qrs}$ & $19.61 \mathrm{a}$ & $0.47 \mathrm{o}-\mathrm{r}$ & $6.80 \mathrm{a}$ \\
G7 & $9.57 \mathrm{c}$ & $0.58 \mathrm{~m}-\mathrm{p}$ & $0.86 \mathrm{j}-\mathrm{m}$ & $3.67 \mathrm{c}$ \\
G8 & $1.07 \mathrm{hij}$ & $1.02 \mathrm{ijk}$ & $0.76 \mathrm{j}-\mathrm{n}$ & $0.95 \mathrm{f}$ \\
G9 & $0.63 \mathrm{mno}$ & $0.16 \mathrm{tu}$ & $1.41 \mathrm{~h}$ & $0.73 \mathrm{~g}$ \\
G10 & $0.78 \mathrm{j}-\mathrm{n}$ & $0.34 \mathrm{qrs}$ & $0.29 \mathrm{rst}$ & $0.47 \mathrm{~h}$ \\
G11 & $3.70 \mathrm{f}$ & $1.20 \mathrm{hi}$ & $1.23 \mathrm{hi}$ & $2.04 \mathrm{e}$ \\
G12 & $0.37 \mathrm{p}-\mathrm{s}$ & $7.67 \mathrm{~d}$ & $0.26 \mathrm{rst}$ & $2.77 \mathrm{~d}$ \\
\hline Average** & $\mathbf{1 . 8 3 ~ b}$ & $\mathbf{4 . 2 9} \mathbf{~ a}$ & $\mathbf{0 . 6 0} \mathrm{c}$ & \\
\hline
\end{tabular}

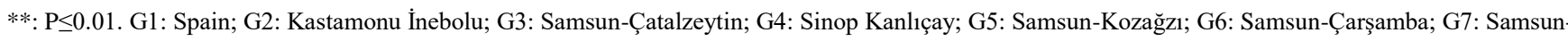
Bağkur; G8: Samsun- Baruthane; G9: Samsun-Nebyan; G10: Samsun-Kurupelit; G11: Sinop-Tıngıroğlu; G12: Samsun-Kavak. 
Different researchers reported that Psoraleae varieties have a rich content of psoralen and angelicin, and they are used traditional medicine (Rakhmankulov \& Korotkova 1975; Cappelletti et al. 1984). Baskaran et al. (2001) and Milesi et al. (2001) indicated that the psoralen is used for the photochemotherapy of vitiligo and skin diseases such as psoriasis, mycosis fungoidies, and eczema. Besides, psoralen inhibits cancer (Oliveira et al. 2006). Angelicin is used for determining DNA/RNA structures in cells and microorganisms, and the treatment of psoriasis (Kittler et al. 1980). Previous researches showed greater variability in psoralen and angelicin contents between Psoralea varieties. This may be due to genetic differences and environmental factors. Li et al. (2018) found that the psoralen and angelicin contents of Psoralea gingivalis were 6250 and 3125 ppm, respectively, while Ahandani et al. (2013) determined that psoralen and angelicin contents of Psoraleae plumose were at 2744 and 3022 ppm, respectively. Psoralen and angelicin contents may vary differences in the organs of plants. For example, Del Río et al. (2010) determined that the psoralen and angelicin content of Psoralea bituminosa leaves ranged between 2204-3416 and 2530-3918 ppm, respectively. On the other hand, Ahandani et al. (2013) indicated that the seeds of Psoralea corylifolia content of psoralen and angelicin were at 7800 and 2300 ppm, respectively. The angelicin and psoralen contents in this study are different from previous studies. This may be due to the varieties and ecological conditions.

The contents of daidzein and genistein determined in B. bituminosa leaf extracts are given in Tables 6 and Table 7 . The daidzein content of genotypes was ranged from $3.66 \mathrm{ppm}$ (genotype number 1 at the beginning of flowering) to $37.57 \mathrm{ppm}$ (genotype number 5 at the budding period). When the growth periods were compared, the highest daidzein content was found at the beginning of growth (18.27 ppm) and the lowest daidzein content was found in the budding period (14.78 ppm) (Table 6). The highest genistein content was determined in genotype number 9 at the beginning of growth (6.34 ppm), while the lowest genistein content was determined in genotype number 8 in budding period $(1.27 \mathrm{ppm})$. The genistein content in the growth periods from highest to lowest was at the beginning of growth, beginning of flowering and in the budding, respectively. When the genotypes were compared, the highest genistein content was determined in genotype number 9 (4.99 ppm) (Table 7).

Table 6- Daidzein contents of B. bituminosa (ppm)

\begin{tabular}{lccc|c}
\hline Genotypes & Beginning of growth & Budding & Beginning of flowering & Average $^{* *}$ \\
\hline G1 & $9.74 \mathrm{op}$ & $6.76 \mathrm{r}$ & $3.66 \mathrm{t}$ & $6.72 \mathrm{j}$ \\
G2 & $10.63 \mathrm{o}$ & $5.42 \mathrm{~s}$ & $13.24 \mathrm{n}$ & $9.76 \mathrm{i}$ \\
G3 & $20.22 \mathrm{~h}$ & $12.99 \mathrm{j}$ & $27.81 \mathrm{c}$ & $20.34 \mathrm{c}$ \\
G4 & $9.30 \mathrm{pq}$ & $18.05 \mathrm{n}$ & $15.30 \mathrm{~m}$ & $14.21 \mathrm{~g}$ \\
G5 & $19.44 \mathrm{hi}$ & $37.57 \mathrm{a}$ & $17.56 \mathrm{jk}$ & $24.86 \mathrm{~b}$ \\
G6 & $17.59 \mathrm{jk}$ & $9.53 \mathrm{pq}$ & $26.84 \mathrm{~cd}$ & $17.99 \mathrm{e}$ \\
G7 & $21.30 \mathrm{~g}$ & $16.06 \mathrm{~lm}$ & $15.39 \mathrm{~lm}$ & $17.58 \mathrm{ef}$ \\
G8 & $26.26 \mathrm{~d}$ & $7.21 \mathrm{r}$ & $18.62 \mathrm{ij}$ & $17.36 \mathrm{f}$ \\
G9 & $30.92 \mathrm{~b}$ & $24.27 \mathrm{e}$ & $30.90 \mathrm{~b}$ & $28.70 \mathrm{a}$ \\
G10 & $18.38 \mathrm{ij}$ & $8.50 \mathrm{q}$ & $16.57 \mathrm{kl}$ & $14.48 \mathrm{~g}$ \\
G11 & $16.10 \mathrm{~lm}$ & $22.43 \mathrm{q}$ & $15.47 \mathrm{~lm}$ & $13.39 \mathrm{~h}$ \\
G12 & $19.36 \mathrm{hi}$ & $\mathbf{1 4 . 7 8 ~ c}$ & $15.56 \mathrm{~lm}$ & $19.12 \mathrm{~d}$ \\
\hline Average** & $\mathbf{1 8 . 2 7} \mathbf{~ a ~}$ & & & \\
\hline
\end{tabular}

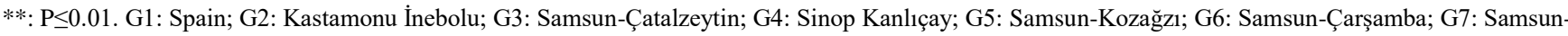
Bağkur; G8: Samsun- Baruthane; G9: Samsun-Nebyan; G10: Samsun-Kurupelit; G11: Sinop-Tingıroğlu; G12: Samsun-Kavak.

Table 7- Genistein contents of B. bituminosa (ppm)

\begin{tabular}{lccc|c}
\hline Genotypes & Beginning of growth & Budding & Beginning of flowering & Average $^{* *}$ \\
\hline G1 & $1.92 \mathrm{qr}$ & $1.60 \mathrm{st}$ & $1.71 \mathrm{st}$ & $1.74 \mathrm{~h}$ \\
G2 & $2.29 \mathrm{op}$ & $3.12 \mathrm{jk}$ & $3.49 \mathrm{gh}$ & $2.96 \mathrm{de}$ \\
G3 & $5.65 \mathrm{~b}$ & $3.32 \mathrm{hi}$ & $4.69 \mathrm{~d}$ & $4.55 \mathrm{~b}$ \\
G4 & $1.76 \mathrm{rs}$ & $2.65 \mathrm{n}$ & $3.60 \mathrm{~g}$ & $2.67 \mathrm{f}$ \\
G5 & $3.92 \mathrm{f}$ & $2.44 \mathrm{o}$ & $2.77 \mathrm{mn}$ & $3.04 \mathrm{~d}$ \\
G6 & $3.83 \mathrm{f}$ & $2.20 \mathrm{p}$ & $3.02 \mathrm{kl}$ & $3.01 \mathrm{~d}$ \\
G7 & $2.22 \mathrm{p}$ & $2.29 \mathrm{op}$ & $2.27 \mathrm{op}$ & $2.26 \mathrm{~g}$ \\
G8 & $3.80 \mathrm{f}$ & $1.27 \mathrm{u}$ & $3.01 \mathrm{kl}$ & $2.69 \mathrm{f}$ \\
G9 & $6.34 \mathrm{a}$ & $5.26 \mathrm{c}$ & $3.38 \mathrm{hi}$ & $4.99 \mathrm{a}$ \\
G10 & $3.29 \mathrm{ij}$ & $1.57 \mathrm{t}$ & $4.13 \mathrm{e}$ & $2.99 \mathrm{de}$ \\
G11 & $3.84 \mathrm{f}$ & $2.96 \mathrm{q}$ & $3.00 \mathrm{kl}$ & $2.89 \mathrm{e}$ \\
G12 & $4.18 \mathrm{e}$ & $2.90 \mathrm{~lm}$ & $\mathbf{3 . 1 6} \mathbf{~ b}$ & $3.36 \mathrm{c}$ \\
\hline Average** & $\mathbf{3 . 5 9} \mathbf{~ a ~}$ & $\mathbf{2 . 5 5} \mathbf{c}$ & & \\
\hline
\end{tabular}

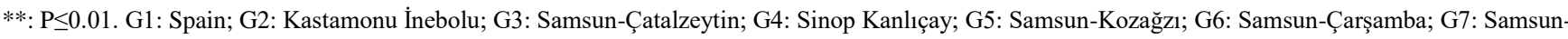
Bağkur; G8: Samsun- Baruthane; G9: Samsun-Nebyan; G10: Samsun-Kurupelit; G11: Sinop-Tıngıroğlu; G12: Samsun-Kavak. 
Adlercreutz et al. (1991) and Setchell et al. (1981) explained that the daidzein has reduced breast cancer occurrence, and play a key role in the protection against colon cancer. Bouquet et al. (1998) reported that the daidzein concentration of Psoraleae varieties is greater in the stems than in the leaves, and it was ranged between 174-6072 ppm. Genistein is a secondary matter an estrogenic preventing bone resorption and promotes increased bone density (Anderson et al. 1995; Arjmandi et al. 1996; Alekel et al. 2000). Hsu et al. (2001) reported that the genistein content of Psoralea corylifolia was at 7800 ppm. Mustonen et al. (2018) reported daidzein and genistein content of red clover were ranged between 250-310 and 490-550 ppm, respectively. Our results showing a great difference between the previous studies. Sivesind \& Seguin (2005) indicated that if there are environmental effects (soil) and plant phenological traits (plant age and growth period), the variety choice will influence most on isoflavonoid amounts. Besides, Kallela et al. (1988) and Saloniemi et al. (1995) reported that the isoflavone content of the plants was higher in the early growth periods than in the late periods. Similarly, in this study, daidzein and genistein content of the beginning of growth was higher than other growing periods.

The contents of daidzin and genistin determined in B. bituminosa leaf extracts were given in Tables 8 and Table 9. When Table 8 is examined, the daidzin content of B.bituminosa genotypes showed change among growth periods. The daidzin content of the plant between $0 \mathrm{ppm}$ and $381.66 \mathrm{ppm}$. Accordingly, the highest daidzin content was determined in genotype number 6 at the beginning of flowering. When the growth periods were compared, the highest daidzin content was found at the beginning of flowering $(113.05 \mathrm{ppm})$ and the lowest daidzin content was found at the beginning of growth (25.46 ppm) (Table 8). Genistin contents of genotypes ranged from 0 ppm to $330.14 \mathrm{ppm}$, while the highest genistin was obtained from genotype number 6 and in the beginning of growth (Table 9). Genistin content was not found in many genotypes especially in the budding period. Besides, when the genotypes were compared, the highest genistin content was determined in genotype number 3 (137.82 ppm) (Table 9).

Table 8- Daidzin contents of B. bituminosa (ppm)

\begin{tabular}{lccc|c}
\hline Genotypes & Beginning of growth & Budding & Beginning of flowering & Average $^{* *}$ \\
\hline G1 & $000 \mathrm{~F}$ & $55.52 \mathrm{q}$ & $1.92 \mathrm{~A}$ & $19.14 \mathrm{j}$ \\
G2 & $3.55 \mathrm{y}$ & $000 \mathrm{~F}$ & $8.93 \mathrm{u}$ & 4.161 \\
G3 & $102.78 \mathrm{~m}$ & $0.83 \mathrm{C}$ & $18.65 \mathrm{~s}$ & $40.75 \mathrm{~h}$ \\
G4 & $1.18 \mathrm{~B}$ & $231.53 \mathrm{c}$ & $222.29 \mathrm{e}$ & $151.66 \mathrm{~b}$ \\
G5 & $3.33 \mathrm{y}$ & $275.09 \mathrm{~b}$ & $224.47 \mathrm{~d}$ & $167.63 \mathrm{a}$ \\
G6 & $0.31 \mathrm{E}$ & $000 \mathrm{~F}$ & $381.66 \mathrm{a}$ & $127.32 \mathrm{~d}$ \\
G7 & $79.76 \mathrm{o}$ & $412.98 \mathrm{l}$ & $146.07 \mathrm{~h}$ & $112.94 \mathrm{e}$ \\
G8 & $0.96 \mathrm{C}$ & $182.78 \mathrm{~g}$ & $2.15 \mathrm{z}$ & $15.66 \mathrm{k}$ \\
G9 & $8.33 \mathrm{v}$ & $75.70 \mathrm{p}$ & $4.31 \mathrm{x}$ & $65.14 \mathrm{~g}$ \\
G10 & $7.53 \mathrm{w}$ & $115.10 \mathrm{k}$ & $15.86 \mathrm{t}$ & $33.03 \mathrm{i}$ \\
G11 & $89.71 \mathrm{n}$ & $126.85 \mathrm{j}$ & $190.99 \mathrm{f}$ & $131.93 \mathrm{c}$ \\
G12 & $8.06 \mathrm{v}$ & $\mathbf{1 0 1 . 6 9 ~ b}$ & $139.34 \mathrm{I}$ & $91.41 \mathrm{f}$ \\
\hline Average** & $\mathbf{2 5 . 4 6 ~ c}$ & $\mathbf{1 1 3 . 0 5 ~ a}$ & \\
\hline
\end{tabular}

**: $\mathrm{P} \leq 0.01$ (While the interactions were lettered, capital letters were continued after the lowercase letters were finished). G1: Spain; G2: Kastamonu İnebolu; G3: Samsun-Çatalzeytin; G4: Sinop Kanlıçay; G5: Samsun-Kozağz1; G6: Samsun-Çarşamba; G7: Samsun-Bağkur; G8: Samsun- Baruthane; G9: SamsunNebyan; G10: Samsun-Kurupelit; G11: Sinop-Tıngıroğlu; G12: Samsun-Kavak.

Table 9- Genistin contents of $B$. bituminosa (ppm)

\begin{tabular}{lccc|c}
\hline Genotypes & Beginning of growth & Budding & Beginning of flowering & Average** \\
\hline G1 & $000 \mathrm{r}$ & $000 \mathrm{r}$ & $30.96 \mathrm{n}$ & $10.32 \mathrm{j}$ \\
G2 & $130.31 \mathrm{f}$ & $38.11 \mathrm{l}$ & $130.30 \mathrm{f}$ & $99.57 \mathrm{e}$ \\
G3 & $40.89 \mathrm{k}$ & $241.67 \mathrm{~b}$ & $130.89 \mathrm{ef}$ & $137.82 \mathrm{a}$ \\
G4 & $167.31 \mathrm{c}$ & $163.98 \mathrm{~d}$ & $15.85 \mathrm{o}$ & $115.71 \mathrm{c}$ \\
G5 & $244.51 \mathrm{~b}$ & $000 \mathrm{r}$ & $85.57 \mathrm{~h}$ & $110.02 \mathrm{~d}$ \\
G6 & $330.14 \mathrm{a}$ & $000 \mathrm{r}$ & $34.95 \mathrm{~m}$ & $121.69 \mathrm{~b}$ \\
G7 & $6.86 \mathrm{p}$ & $000 \mathrm{r}$ & $000 \mathrm{r}$ & $2.28 \mathrm{k}$ \\
G8 & $000 \mathrm{r}$ & $000 \mathrm{r}$ & $52.48 \mathrm{I}$ & $17.49 \mathrm{~h}$ \\
G9 & $000 \mathrm{r}$ & $000 \mathrm{r}$ & $131.09 \mathrm{ef}$ & $43.69 \mathrm{~g}$ \\
G10 & $000 \mathrm{r}$ & $000 \mathrm{r}$ & $44.97 \mathrm{j}$ & $14.99 \mathrm{I}$ \\
G11 & $133.29 \mathrm{e}$ & $000 \mathrm{r}$ & $15.19 \mathrm{o}$ & $49.49 \mathrm{f}$ \\
G12 & $38.02 \mathrm{l}$ & $0.23 \mathrm{q}$ & $109.35 \mathrm{~g}$ & $49.20 \mathrm{f}$ \\
\hline Average** & $\mathbf{9 0 . 9 4} \mathbf{~ a}$ & $\mathbf{3 7 . 0 0 ~ c}$ & $\mathbf{6 5 . 1 3 ~ b}$ & \\
\hline
\end{tabular}

**: P $\leq$ 0.01. G1: Spain; G2: Kastamonu İnebolu; G3: Samsun-Çatalzeytin; G4: Sinop Kanlıçay; G5: Samsun-Kozağzı; G6: Samsun-Çarşamba; G7: SamsunBağkur; G8: Samsun- Baruthane; G9: Samsun-Nebyan; G10: Samsun-Kurupelit; G11: Sinop-Tıngıroğlu; G12: Samsun-Kavak. 
Daidzin and genistin is a natural organic compound in the class of phytochemicals known as isoflavones. Bituminaria bituminosa was less than daidzein and genistein content compared to the previous studies. Lojza et al. (2004) reported that daidzein and genistein content of soybean ranged between 249-468 and 280-618 ppm, respectively. On the other hand, the harvest time has influenced daidzin and genistin. This indicates that the plant secretes metabolites at different times.

Table 10 shows binary relationships among secondary metabolites in terms of the mean values of B. bituminosa genotypes. Accordingly, a negative and very important relationship was found between psoralen with angelicin $(r=-0.690)$ and genistin $(r$ $=0.755$ ). In other words, increased psoralen in genotypes lead to a decrease in angelicin and genistin and vice versa. Besides, while there was a negative and significant relationship between furanocoumarins (psoralen and angelicin), a significant and positive relationship was found between isoflavonoids (daidzein, genistein) and isoflovan glycosides (daidzin and genistin).

Table 10- Bilateral relationships between secondary metabolites of $B$. bituminosa genotypes

\begin{tabular}{lccccc}
\hline & Angelicin & Daidzein & Genistein & Daidzin & Genistin \\
\hline Psoralen & $-0.690^{* *}$ & 0.230 & -0.343 & -0.121 & $-0.755^{* *}$ \\
Angelicin & & 0.032 & 0.232 & 0.157 & 0.439 \\
Daidzein & & 0.078 & -0.208 & -0.018 \\
Genistein & & & 0.460 & 0.415 \\
Daidzin & & & & 0.216 \\
\hline
\end{tabular}

$$
* *: \mathrm{P} \leq 0.01
$$

To determine the multivariate relationships between the secondary metabolite values of B. bituminosa genotypes, biplot analysis, which is the principal component analysis (PCA) of both genotypes and secondary metabolites, was carried out. Biplot analysis was performed by comparing PC1 and PC2 values. When the biplot graph is examined, PC1 (Main component 1) is $42.0 \%$ and PC2 (Main component 2) is $26.6 \%$ and the total variation is $68.6 \%$. In the first group, since the angle value between the vectors belonging to the properties of angelicin and genistin is $90^{\circ}$ lower, these two properties are in the same group. In the second group, the angle between the vectors belonging to genistein, daidzein and daidzin content is found to be less than $90^{\circ}$ and these properties are in the same group. The third group is the psoralen vector. In the biplot graph, genotype number $2,3,4$ and 6 are prominent in terms of content of angelicin and genistin. In the second group, genotype number 9 and 12 are prominent in terms of content of genistein, daidzein and daidzin. Genotypes number 5, 7, 8 and 10 fall into the same group in terms of psoralen (Figure 1). 


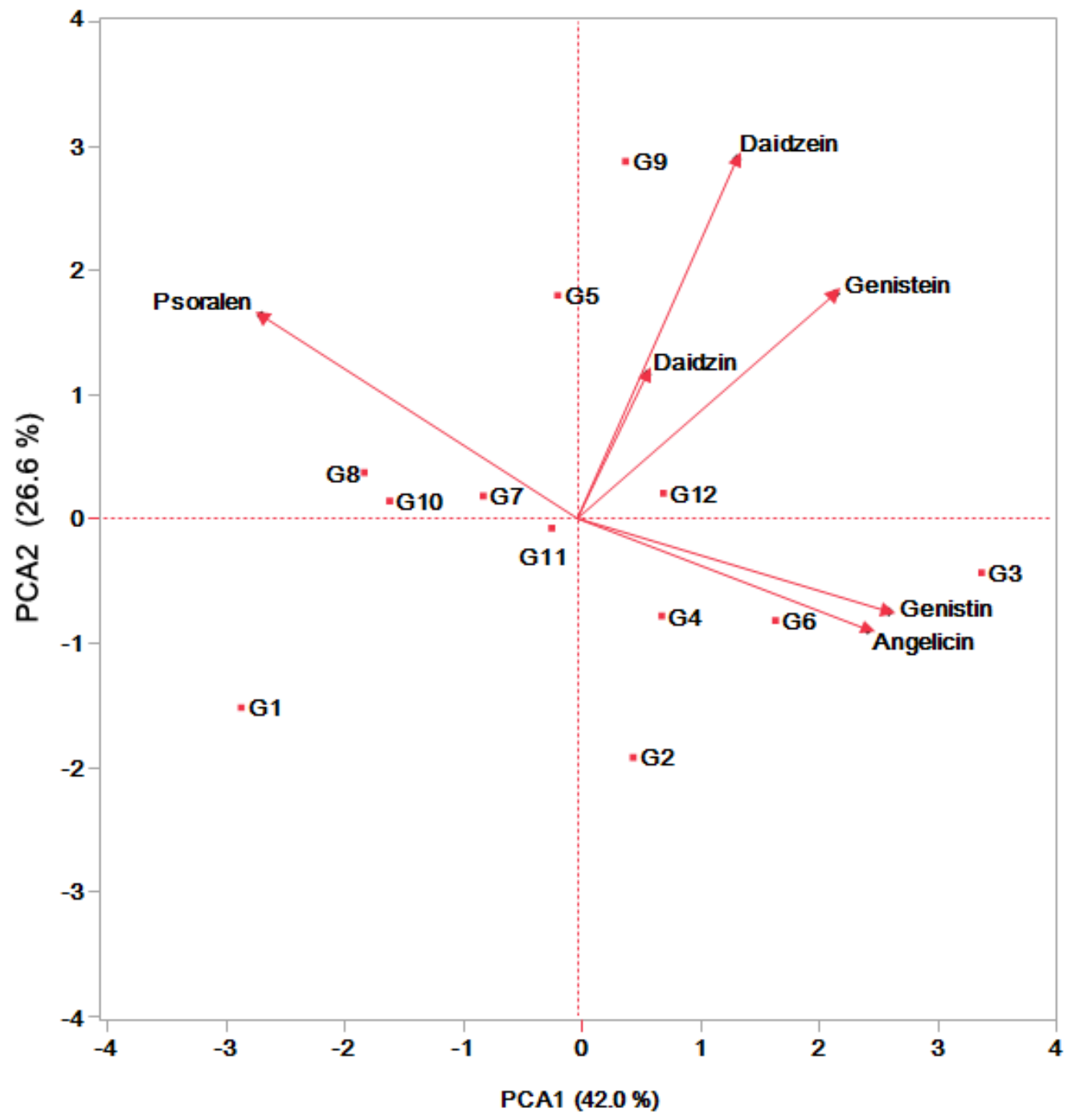

Figure 1- Principal Component Analysis of secondary metabolites of B. bituminosa

G1: Spain; G2: Kastamonu İnebolu; G3: Samsun-Çatalzeytin; G4: Sinop Kanlıçay; G5: Samsun-Kozağz1; G6: Samsun-Çarşamba; G7: Samsun-Bağkur; G8: Samsun- Baruthane; G9: Samsun-Nebyan; G10: Samsun-Kurupelit; G11: Sinop-Tıngıroğlu; G12: Samsun-

Kavak

\section{Conclusions}

Secondary metabolites determined in leaf samples of $B$. bituminosa were found to be different both in genotypes and growth periods. When the growth periods were compared, it was found that furanocoumarins (psoralen and angelicin) and isoflovan glycosides (daidzin and genistin) showed a change in B. bituminosa leaves and these varied in three different growth periods. However, isoflavonoids (daidzein, genistein) were found to be higher in the beginning of growth than the other two periods.

On the other hand, as a result, all genotypes performed remarkably in terms of secondary metabolites. Besides, the number 12 genotype (Samsun-Kavak) was prominent in terms of angelicin, daidzein, genistein, daidzin, and genistin compared to the other genotypes.

In the literature, there is limited study on the changes in the amount of secondary metabolites both in different genotypes and in different growth periods of $B$. bituminosa. In this respect, the present study fills this gap. At the same time, the study will shed light on future studies about $B$. bituminosa.

\section{Acknowledgements}

The authors wish to thank the Scientific and Technological Research Council of Turkey (TUBITAK) for financial support of this project under Grant No. TOVAG 1180047. This text has been proofread and edited by the School of Foreign Languages of staff, Bilecik Şeyh Edebali University. 


\section{References}

Adlercreutz H, Mousavi Y, Loukovaara M \& Hämäläinen E (1991). Lignans, isoflavones, sex hormone metabolism and breast cancer. In: R B Hochberg \& F Naftolin (Eds.) The New Biology of Steroid Hormones, New York, Raven Press, pp.145-154

Ahandani E A, Abdel Gawwad M R \& Yavari A (2013). Extraction and preparation of Psoralen from different plant part of Psoralea corylifolia and Psoralen increasing with some elicitors. Journal of Plant Biology Research 2(1): 25-37

Arjmandi B H, Alekel L, Hollis B W, Amin D, Stacewicz-Sapuntzakis M, Guo P \& Kukreja S C (1996). Dietary soybean protein prevents bone loss in an ovariectomized rat model of osteoporosis. The Journal of Nutrition 126(1): 161-67. https://doi.org/ 10.1093/jn/126.1.161.

Alekel D L, Germain A S, Peterson C T, Hanson K B, Stewart J W, Toda T (2000). Isoflavone- rich soy protein isolate attenuates bone loss in the lumbar spine of perimenopausal perimenopausal women. The American Journal of Clinical Nutrition 72(3): 679-80. https://doi.org/10.1093/ajen/72.3.844.

Anderson J J, Ambrose W W \& Garner S C (1995). Orally dosed genistein from soy and prevention of cancellous bone loss in two ovariectomized rat models. The Journal of Nutrition 125: $799 \mathrm{~S}$

Baskaran P I \& Jayabalan N (2001). Effect of growth regulators on rapid micropropagation and psoralen production in Psoralea corylifolia L. Acta Physiologiae Plantarum 30:345-351. https://doi.org/10.1007/s11738-007-0129-z.

Boardley M, Stirton C H \& Harborne J B (1986). A chemotaxonomic survey of the tribe Psoralea in Africa. Biochemical Systematics and Ecology 14(6): 603-613

Bouque V, Bourgaud F, Nguyen C \& Guckert A (1998). Production of daidzein by callus cultures of Psoralea species and comparison with plants. Plant Cell, Tissue and Organ Culture 53: 35-40. https://doi.org/10.1023/A:1006057211490

Bourgaud F, Nguyen C \& Guckert A (1995) XXII. Psoralea species: in vitro culture and production of furanocoumarins and other secondary metabolites. In Y P S: Bajaj (Eds.) Biotechnology in Agriculture and Forestry, Berlin, Springer-Verlag pp. 388-411

Cappelletti E M, Innocenti G \& Caporale G (1984). Furocoumarins localization in the fruit and seed of Psoralea corylifolia L. Plantes Medicinales-etPhytotherapie 18: 181-1189

Correal E (2012). Bituminaria bituminosa Workshop, 28-30 November, Sassari/Italy

Davis P H (1965). Flora of Turkey and The East Aegean Islands. Edinburgh University Press, Edinburgh.

Del Río J A, Ortuño A, Pérez I, Bennett R G, Real D (2010). Furanocoumarin content in Bituminaria bituminos a varieties and Cullen species. In: C Porqu eddu \& S Ríos (Eds.). The contributions of grasslands to the conservation of Mediterranean biodiversity. Option $\mathrm{s}$ Méditerranéennes: Série A. Sémin aires Méditerranéen, pp. 69-70

Hsu Y T, Wu C J, Chen J M, Yang Y C \& Wang S Y (2001). The presence of three isoflavonoid compounds in Psoralea corylifolia. Journal of Chromatographic Science 39: 441-444. https://doi.org/10.1093/chromsci/39.10.441

Kallela K, Saastamoinen I, Huokuna E \& Hakkola H (1988). Variation in plant oestrogen content between certain red clover cultivars in northern and southern Finland. Suomen Eläinlääkärilehti 94: 287-291

Kittler L, Hradecna Z \& Suhnel J (1980). Cross-link formation of phage lambda DNA in situ photochemically induced by the furocoumarin derivative angelicin. Biochim Biophys Acta 607: 215-220. https://doi.org/10.1016/0005-2787(80)90074-x

Li X, Yu C, Hu Y, Xia X, Liao Y, Zhang J, Chen H, Lu W, Zhou W \& song Z (2018). New application of psoralen and angelicin on periodontitis with anti-bacterial, anti-inflammatory, and osteogenesis effects. Front Cell Infect Microbiol 5: 8:178. https://doi.org/10.3389/fcimb.2018.00178

Lojza J, Schulzová V \& Hajšlová J (2004). Changes of phytoestrogens daidzein, genistein and their glycosides daidzin and genistin and coumestrol during processing of soyabeans. Czech Journal of Food Sciences 22 (Special Issue): 223-226. https://doi.org/10.17221/10666CJFS

Martínez S, Correal E, Real D, Ortuño A Río JA (2010). Bituminaria bituminosa: a source of furanocoumarins of pharmaceutical interest. Drug plants I: $307-322$

Milesi S, Massot B, Gontier E, Bourgaud F \& Guckert A (2001). Ruta graveolens L.: A promising species for the production of furanocoumarins. Plant Science 161:189-199. https://doi.org/10.1016/S0168-9452(01)00413-7

Mustonen E, Tuori M, Kurki P, Isolahti M, Taponen J \& Vanhatalo A (2018). Variety, time of harvest and conditions during growing season have impact on red clover isoflavone content. Agricultural and Food science 27: 102-109. https://doi.org/10.23986/afsci.69781

Oliveira A M A G, Manuela M, Raposo M, Oliveira-Campos A M F, Machado A E H, Puapairoj P, Pedro M, Nascimento M S C, Portela C, Afonso C \& Madalena P (2006). Psoralen analogues: synthesis, inhibitory activity of growth of human tumor cell lines and computational studies. European Journal of Medicinal Chemistry 41: 367-372. https://doi.org/10.1016/j.ejmech.2005.10.016

Pazos-Navarro M, Del Ri'o J A, Ortuño A, Romero-Espinar P, Correal E \& Dabauza M (2013). Plant regeneration from different explant types of Bituminaria bituminosa and furanocoumarin content along plant regeneration stages. Plant Growth Regulation 70: 123-129. https://doi.org/10.1007/s10725-013-9784-9

Pecetti L, Tava A, Pagnotta M A \& Russi L (2007). Variation in forage quality and chemical composition among Italian accessions of Bituminaria bituminosa (L.) Stirt. Journal of the Science of Food and Agriculture 87: 985-991. https://doi.org/10.1002/jsfa.2792

Pistelli L, Noccioli C, Appendino G, Bianchi F, Sterner O \& Ballero M (2003). Pterocarpans from Bituminaria morisiana and Bituminaria bituminosa. Phytochemistry 64: 595-598. https://doi.org/10.1016/s0031-9422(03)00190-0

Rakhmankulov U \& Korotkova E E (1975). Dynamics of the content of furocoumarins in various organs of Psoralea drupacea. Rastitel, nyeResursy 11: 98-104

Real D (2012). Tedera a modern model of species domestication and breeding. Booklet. Department of Agriculture and Food Government of Western Australia.

Saloniemi H, Wähälä K, Nykänen-Kurki P, Kallela K \& Saastamoinen I (1995). Phytoestrogen content and estrogenic effect of legume fodder. Proceedings of the Society for Experimental Biology and Medicine 208: 13-17. https://doi.org/10.3181/00379727-208-43825

Setchell K D R, Lawson A M, Borriello S P, Harkness R, Gordon H, Morgan D M, Kirk D N, Adlercreatz H, Anderson L C \& Axelson M (1981). Lignan formation in man-microbial involvement and possible roles in relation to cancer. The Lancet 2: 4-7. https://doi.org/10.1016/S0140-6736(81)90250-6

Sivesind E \& Seguin P (2005). Effects of the environment, cultivar, maturity, and preservation method on red clover isoflavone concentration. Journal of Agricultural and Food Chemistry 53: 6397-6402. https://doi.org/10.1021/jf0507487

Tava A, Pecetti L, Ricci M, Pagnotta M A \& Russi L (2007). Volatile compounds from leaves and flowers of Bituminaria bituminosa (L.) Stirt. (Fabaceae) from Italy. Flavour Flavour and Fragrance Journal 22: 363-370. https://doi.org/10.1002/ffj.1806 
Walker D J, Moñino I \& Correal E (2006). Genome size in Bituminaria bituminosa (L.) C.H. Stirton (Fabaceae) populations: Separation of "true" differences from environmental effects on DNA determination. Environmental and Experimental Botany 55: 258-265. https://doi.org/10.1016/j.envexpbot.2004.11.005

(C) 2022 by the author(s). Published by Ankara University, Faculty of Agriculture, Ankara, Turkey. This is an Open Access article distributed under the terms and conditions of the Creative Commons Attribution (CC BY) license (http://creativecommons.org/licenses/by/4.0/), which permits unrestricted use, distribution, and reproduction in any medium, provided the original work is properly cited. 